\title{
DOI: https://doi.org/10.25146/2587-7844-2021-15-3-87
}

\section{УДК 378}

\section{ЧУДЕСНЫЕ КАМНИ СОВЕТСКОЙ ЭПОХИ В СКАЗАХ П.П. БАЖОВА}

\section{Ян Юйбин (Екатеринбург, Россия)}

\section{Аннотация}

В статье на основе анализа литической составляющей сказов П.П. Бажова 1940-х гг. доказывается, что эти сказы продолжают традицию, заложенную сказами 1930-х гг., в которых основными камнями, отражающими специфику горнозаводской жизни, выступали малахит, медный изумруд и хризолит. Литический дискурс новых сказов, в которых фигурируют солнечный камень, ключ-камень, терпеливый камешек, позволяет расширить представление как об идейной составляющей сказов, так и о мифопоэтике сказового творчества писателя в целом.

Цель статьи заключается в исследовании литической составляющей военных и послевоенных сказов Бажова, в которых через изображение как реально существующих, так и чудесных камней нового времени просматриваются контуры будущей счастливой жизни советского народа.

Методология. В статье используется методика культурно-исторического, идейнообразного и символико-контекстуального анализа.

Результаты исследования и выводы. В статье последовательно рассматривается ряд камней, которые по своему внешнему виду и символическим свойствам могут претендовать на статус камней новой советской эпохи на Урале. Среди этих камней мы видим как реально существующие камни (гелиолит, золотистый топаз, родонит), которые по внешнему виду и символическим литическим свойствам могут претендовать на статус камней новой советской эпохи в «сказах о Ленине», так и чудесные камни (ключ-камень, терпеливый камешек, золотоцветень горы). Последние позволяют оценить утопический потенциал счастливого будущего советского Урала, который с точки зрения 1940-х гг. не казался Бажову абсолютно недостижимым.

Ключевые слова: П.П. Бажов, сказы, литический дискурс, чудесные камни советской эпохи (ключ земли, терпеливый камешек, золотоиветень горы).

оссия по праву считается родиной множества драгоценных и полудрагоценных камней. Особое место среди этих минералов занимают уральские самоцветы - камни, добывающиеся на границе между Европой и Азией. Не случайно эту территорию назвали самоцветной полосой Урала. Е.Э. Иванова так определяет смысл этого термина: «Самоцветная полоса Урала - это условное название территории, протянувшейся с севера на юг более чем на 100 км, вдоль восточного склона Среднего Урала, в верховьях рек Нейва, Реж и Адуй. Здесь расположены богатые месторождения минералов: топазов, турмалинов, изумрудов, аметистов, рубинов, сапфиров, аквамаринов, морионов, горного хрусталя и других ценных камней» [Иванова, 2020, с. 108]. По мнению исследовательницы, история самоцветной полосы насчитывает более 
350 лет, само название появилось лишь в начале XX века. Автором данного термина был основатель и глава Уральской минералогической школы, профессор кафедры минералогии Уральского горного института К.К. Матвеев.

В целом для Урала характерно упование на Гору, на спасительную силу и власть камня как литического топоса Урала. Сама красота уральской земли мыслится как красота, заключенная под землей, в каменных пещерах. А драгоценные камни «самоцветной полосы» - это ключ, открывающий пещеру.

$\mathrm{B}$ XX веке известный уральский писатель Павел Петрович Бажов сделал минералы «самоцветной полосы» одним из основных героев своих сказов, прославив «каменный пояс» Урала не только на всю Россию, но и на весь мир. Среди камней, символизирующих традиционную литическую власть Уральских гор дореволюционного периода в сказах Бажова 1930-х гг., времени создания сборника «Малахитовая шкатулка», выделялись своей значимостью малахит, медный изумруд и хризолит.

Малахит является настоящей гордостью Урала. Своеобразие уральского малахита заключается в его специфическом пестром зеленом окрасе, вызванном высоким содержанием меди. Разные оттенки зеленого цвета приобретают вид колец и нитей различных размеров, что позволяет использовать самоцвет не только для создания украшений, но и производства облицовочных плит, которыми инкрустируют стены, шкатулки, столы.

В сказах Бажова малахит характеризуется как «камень небывалой радости и широкой силы», в котором «радость земли собрана» («Железковы покрышки») [Бажов, 2019, с. 407]. Малахит - символ Хозяйки Медной горы, которая характеризуется в сказах как Малахитница. По словам поэтессы М. Никулиной, малахитовая шкатулка с разным женским прибором, которую Хозяйка Медной горы своими руками Степану подала, «стала символом Урала, и никто, никогда с этим не спорил» [Никулина, 2002, с. 38].

Медный изумруд, который академик А.Е. Ферсман назвал «славой и гордостью Урала» (Д.Е. Ферсман, 1974), появляется у Бажова сразу в двух сказах: «Медной горы Хозяйка» и «Сочневы камешки». В XIX веке этот минерал считали разновидностью настоящего изумруда и наделяли исключительной магической силой. По преданию, медный изумруд рождается из желчи змеи, что символично само по себе, поскольку змеи и ящерицы традиционно рассматриваются в качестве зооморфных символов (животных ипостасей) Хозяйки Медной горы. По справедливому мнению, высказанному О.И. Гамали и О.Б. Каневской, «медный изумруд, символизируя абсолютную власть каменной силы, является воплощением тайного богатства гор, недоступного простым смертным» [Гамали, 2016, с. 32].

Третьим камнем, олицетворяющим собой литическую власть Уральских гор, является у Бажова хризолит. В отличие от малахита и медного изумруда, хризолит у Бажова - это воплощение сказов «детского тона», к которым принадлежат такие сказы, как «Огневушка-поскакушка» и «Серебряное копытце». По мнению Л. Скорино, сказы «детского тона», «не драматичны, как сказы 
“взрослого тона”, а, наоборот, оптимистичны, пронизаны веселым лукавством рассказчика и всегда заканчиваются призывом не удовлетворяться найденным, а снова искать, открывать» [Скорино, 1947, с. 173].

Во всех случаях специфика «уральского романа с камнем» заключается в том, что камень рассматривается не как драгоценность, которая может обогатить человека, но как некая «тайная сила», испытывающая человека на прочность [Никулина, 2002, с. 16].

В творчестве писателя 1940-х гг. именно литическая составляющая позволяет расширить представление как об идейной составляющей сказов, так и о мифопоэтике сказового творчества писателя в целом, когда на смену малахиту, изумрудам и хризолитам эпохи «старого Урала» приходят ключ-камень, солнечный камень и «терпеливый камешек» советской эпохи.

Цель статьи заключается в исследовании литической составляющей военных и послевоенных сказов Бажова, в которых через изображение как реально существующих, так и чудесных камней нового времени просматриваются контуры будущей счастливой жизни советского народа. В этой новой жизни, пронизанной утопической верой в мудрость вождей и коллективный разум советского народа, люди окончательно перестают смотреть на драгоценные и полудрагоценные камни как на источник наживы.

Методология (материаль и метод). В качестве материала исследования выступают сказы Бажова «Ключ земли», «Далевое глядельце», «Золотоцветень горы», а также сказы о В.И. Ленине («Солнечный камень», «Богатырева рукавица», «Орлиное перо»). В статье используется методология культурноисторического, идейно-образного и символико-контекстуального анализа. Культурно-исторический анализ позволяет осмыслить бажовское отношение к сказам в условиях непростой политико-идеологической ситуации в СССР послевоенной эпохи. Анализ места литического дискурса и его специфика в мире бажовских сказов определяет идейно-образный подход к проблеме, в то время как конкретная символика камней-самоцветов позволяет использовать традицию символико-контекстуального анализа. Все ссылки на сказы, кроме сказа «Золотоцветень горы», даются по научному изданию «Малахитовой шкатулки», выпущенному издательством «Кабинетный ученый» (Москва, Екатеринбург) к 140-летию со дня рождения П.П. Бажова.

Результаты исследования. В определенном смысле Бажова можно, без сомнения, назвать советским человеком. Не случайно он называл себя «журналистом первого призыва», подчеркивая свою принадлежность к литераторам, рожденным Октябрем и утверждающим его идеи. По мнению первого биографа писателя Л. Скорино, «сам Бажов принадлежал к коренной русской интеллигенции из демократических слоев, какая... после октября 1917 года пошла за большевиками и подняла огромные пласты революционной работы» [Блажес, Литовская, 2007, с. 382]. С точки зрения В.В. Блажеса, слово «журналист» было для П.П. Бажова синонимом слов «партработник», «политработник»: писатель считал главной 
в своей деятельности партийную направленность - именно она была сущностной и живоносной силой всей его послеоктябрьской жизни [Блажес, 1982].

Много информации о размышлениях Бажова о месте сказов в современной советской литературе дают эпистолярии писателя послевоенной эпохи ${ }^{1}$. Одна из важнейших мыслей писателя, к которой он возвращается из письма в письмо: способность сказов отразить в себе реалии современной, то есть не просто постреволюционной, но послевоенной эпохи. И сделать это с упором именно на уральский материал. В воспоминаниях писателя К. Боголюбова «Наш Бажов» Бажов говорит: «То, что сказы мои уральские - вот в чем главное» [Боголюбова, 1951]. Мечтая создавать историческую прозу романного формата или, в крайнем случае, жанрового формата исторической повести, писатель прекрасно понимал реальную неисполнимость этих мечтаний. Так, раскрывая А.М. Ступникеру свои замыслы исторической повести, посвященной атаману Золотому в 1947 году, он печально заключал: «...все это пока лишь сырье, над которым едва ли стоит работать теперь. Лучше уж буду продолжать оформление сказового материала» [Бажов, 2018, с. 482]. Еще раньше в письме к О.Д. Иваненко (январь 1946 г.) писатель констатировал: «Надеюсь все же преодолеть эти мечты о запоздалом романе и буду, сколько смогу, продолжать попрежнему свою мелочь. Так, во всяком случае, надежнее» [Бажов, 2018, с. 311 ]. Под «мелочью» понимаются сказы.

Причины невозможности работать с жанрами крупных форматов Бажов видел как в своем пожилом возрасте, так и в литературной политике послевоенных лет, требующей создания произведений на актуальные современные темы.

Бажов же вполне искренно хотел видеть сказы современным советским жанром уральской словесности и очень расстраивался, когда на них смотрели только как на «старину». Еще в письме к Л. Скорино в 1944 году он видел задачу изображения «старого быта» в освещении того, «из чего росла любовь к родине и мощь нашего государства» [Бажов, 2018, с. 189]. Положение писателя ухудшилось после появления печально известного Постановления оргбюро ЦК ВКП (б) «О журналах „Звезда” и „Ленинград”» от 14 августа 1946 года. В последующем за Постановлением выступлении А. Жданова даже А. Ахматова получила упрек в том, что она - поэтесса, у «которой в силу разных причин поворота к актуальным темам нет» ${ }^{2}$. В переписке с Л. Скорино Бажов много рассуждает о проблеме современности/несовременности сказов, высказывая свои опасения как за тематику, так и за их жанровую форму. Он пишет: «Из боязни ошибиться начнут действовать обычным способом. Сказка? Нет, не нужно. Легенда? Что вы, батенька, газет разве не читаете? Сказ? Ну, знаете, подальше от всяких сказов! Нам нужна

\footnotetext{
1 Эпистолярии Бажова рассматриваются по изданию: «П.П. Бажов. Письма. 1911-1950», где представлены 418 писем, написанных Бажовым в период с 1911 по 1950 год, то есть в течение 39 лет.

2 Подробно об этом: Иофе В.В. К пятидесятой годовщине постановления ЦК ВКП(б) О журналах «Звезда» и «Ленинград» от 14 августа 1946 года // Звезда. 1996. № 8. С. 19.
} 
современность! Понимаете? Современность, а не какие-то там посказульки из старины» [Бажов, 2018, с. 364-365]. Иронизируя над книгой, которую писала о нем Л. Скорино, Бажов заявляет: «Да, нелегко в настоящее время выпустить книгу о сказочнике, когда самая сказка отодвинута на дальний план» [Бажов, Письма, 2018, с. 366]. В подобных условиях даже лауреатство Бажова не могло быть стопроцентной защитой от возможной критики: «Вы правы, когда говорите, что к моей манере письма в какой-то степени привыкли, но не менее привыкли и к мысли, что этот всегда о прошлом пишет. Теперь к этому добавляется - печатать можно, но рядом с “полнокровными, политически-острыми современными произведениями". Иначе говоря, моя работа полностью приравнивается вообще к работам о старине. Современного в ней, кроме Вас и очень немногих, не видят и, думаю, долго не увидят <..>. Попробуйте при таком взгляде доказать, что “Дорогое имячко" - это Октябрьская революция, что “Васина гора" - отражение тех настроений, с каким советские люди приняли пятилетний план, что “Гор подаренье" - праздник Победы и т.д.» [Бажов, 2018, с. 401].

Тем не менее в письмах к близким по духу людям Бажов позволяет себе достаточно горькие признания. В письме Е. Пермяку 1946 года он жалуется: «Скулежное состояние переживаю» [Бажов, 2018, с. 381]. Или: «Ну и началось раскисление: хожу, как потерявший что-то очень важное, и ни черта не делаю, кроме писем по депутатским делам» [Бажов, 2018, с. 382].

В условиях невозможности полноценной работы с уральским историческим материалом Бажов стал видеть именно в уральском сказе - классическую форму времени, жанр, который мог свести воедино прошлое «старого» Урала и его советское настоящее. Поэтому вплоть до своей смерти в 1950 году Бажов отстаивал «современность» своих сказов и писал новые сказы на «современные» темы, перебрасывая тем самым мостик от «старого седого Урала» к Уралу не просто послереволюционному, но Уралу послевоенному.

И литическая тема становилась для писателя одной из основных. В качестве первого сказа, в котором рассматриваются новые чудесные камни советской эпохи, выступает сказ «Ключ земли», впервые опубликованный в 1940 году в газете «Уральский рабочий». Как пишет Д.В. Жердев: «В сказе наиболее полно раскрыт мотив камня-ключа... который в руках героя-посредника, субъекта будущего ритуального союза с тайной силой, должен открыть доступ к “земельному богатству", что, в свою очередь, станет основой построения утопического общества» [Жердев, 2007, с. 209]. Действие сказа происходит «то ли под Мурзинкой, то ли в другом месте» [Бажов, 2019, с. 280] еще при крепостном праве, «при казенном еще положении» [Бажов, 2019, с. 280]. В изображении Бажова это эпоха, когда «начальство в чинах да ясных пуговках, палачи при полной форме, по барабану народ на работу гоняли, под барабан сквозь строй водили, прутьями захлестывали» [Бажов, 2019, с. 280]. Главной героиней сказа является девчушка Васёнка, дочь стряпухи, которая обладает большим талантом искать камни: «чаще всех выхватывала, и камешок самый ловкий, вовсе дорогой» [Бажов, 2019, с. 281]. 
За эту способность девочку прозвали Счастливый Глазок. После того как Васёнка находит «камешок в палец ростом», который уходит вначале в царскую казну, а затем продается за границу, на ней хочет жениться главный щегорь, польстившийся на ее счастье. Бажов характеризует его как пса, который «даром что сам давно зубы съел, и ближе пяти шагов к нему не подходи: пропастиной разит - из нутра протух» [Бажов, 2019, с. 281]. Чтобы избавиться от нежеланного брака, Васёнка зимой бежит с рудника и чуть не замерзает в сугробе, где и видит чудесный сон о счастливом будущем. В нем одну из главных ролей будет играть литический дискурс, чудесные камешки, которыми люди вознаграждаются за свои нравственно-этические достоинства. На каменном столе последовательно появляются дорогие камни, которые «разными огоньками горят, и река от них повеселее стала. Глядеть любо», «одни красным отливают, другие зелеными огоньками посверкивают, голубенькие тоже, желтенькие... всякие» [Бажов, 2019, с. 287]. Самые маленькие даются на простоту, покрупнее - на терпеливого. Крупные камни и красоты редкой даются «на удалого да на счастливый глазок» [Бажов, 2019, c. 287]. Один из этих камешков прилетел и к Васёнке: «как котенок головенкой в руку и ткнулся - тут, дескать, я, возьми» [Бажов, 2019, с. 287].

Однако все эти камни - вполне реальные уральские самоцветы, не обладающие особой символической природой. Другое дело камень - ключ земли (первоначально Бажов хотел назвать сказ «Ключ-камень»). Этот камень, названный сказителем «камень-одинец», появляется на каменном столе и имеет форму пентаграммы: «вовсе простенький, на пять граней: три продольных да две поперечных» [Бажов, 2019, с. 287]. Именно появление этого камня рождает у Васёнки видение «золотого века», которое можно ассоциировать с советской эпохой: «И тут сразу тепло да светло стало, трава и деревья зазеленели, птички запели, и река заблестела, засверкала, запоплескивала. Где голый песок был, там хлеба густые да рослые. И людей появилось многое-множество. Да все веселые. Кто будто и с работы идет, а тоже песню поет» [Бажов, 2019, с. 287]. На вопрос Васёнки, кому предназначен этот камешек, она слышит ответ вполне в духе утопии счастливого общества: «тому, кто верной дорогой народ поведет. Этим ключом-камнем человек землю отворит, и тогда будет, как сейчас видела» [Бажов, 2019, с. 287]. По мнению Д.В. Жердева, в этом сказе, как и в более ранних сказах полевского цикла, «происходит актуализация представлений об Урале как о маргинальной зоне, в которой границы “мира живых” вообще ослаблены. В результате бажовский Урал оказывается магическим центром в области “земельного богатства”» [Бажов, 2007, с. 209]. Необходимо уточнить только один момент. Если в сказах «полевского цикла» «тайная сила» ассоциировалась главным образом с Хозяйкой Медной горы, то в послевоенных сказах она все больше и больше начинает ассоциироваться с вождями советского периода, смело ведущими народ в счастливое будущее, которым открываются все тайны «самоцветной полосы». Наиболее отчетливо эта новая литическая установка проявляет себя у Бажова в сказах о Ленине («Солнечный камень», 
«Богатырева рукавица», «Орлиное перо»), созданных во время Великой Отечественной войны. «Солнечный камень» был опубликован в 1942 году, «Богатырева рукавица» - в 1944 году, «Орлиное перо» - в 1945 году.

Эти сказы объединяет между собой не только тема В.И. Ленина - человека, который повел народ «верной дорогой», но и активный поиск новых чудесных камней советской эпохи, образы которых продолжают тему, начатую «камнем земли», камнем-«одинцом». При этом в каждом из этих сказов выступают вполне реальные камни, приобретающие в советской действительности чудесные функции, позволяющие им стать символами нового мира. В основе сказа «Солнечный камень» лежит история создания Ильменского заповедника по декрету Совнаркома от 14 мая 1920 года, подписанного Лениным. Чтобы добиться этого, в Москву к Ленину идут ходоки, олицетворяющие собой различные типы горнозаводских рабочих. Русский горщик Максим Вахоня, наделенный огромной силой, но простодушный и незлобивый, пытается прельстить Ленина дорогими самоцветами, идущими главным образом на украшения. Однако Ленин остается равнодушным к драгоценным камням, так как «с этим погодить можно» [Бажов, 2019, c. 371]. Но «бачка Ленин» не может устоять перед «солнечным камнем», показанным ему вторым ходоком, башкиром Садыком, который обладает острым и проницательным умом. Он говорит: «Солнечный камень нам нужен. Веселее с ним жить» [Бажов, 2019, с. 371] и подписывает декрет об организации заповедника. Солнечный камень не был выдумкой Бажова. Это вполне реальный камень, относящийся к группе полевых шпатов. Свое название «гелиолит», что в переводе с греческого и означает «солнечный камень», он получил в 1841 году. Солнечный камень со своим золотисто-красным искрящимся свечением в России добывали на Южном Урале, там, где «горы поворот дают и в степь выходят» [Бажов, 2019, с. 371]. Таким образом, камень в сказе одновременно символизировал союз степи и гор, что было важно для многонационального края, и являлся самоцветом, олицетворяющим собой новую советскую действительность Урала.

Сказ «Богатырева рукавица» подвергался критике исследователями за то, что Бажов довел в нем «до крайних пределов... мифологизацию образа Ленина» [Слобожанинова, 1998, с. 137]. Л. Слобожанинова отмечала поразительный «контраст между мастерской обработкой уральской легенды о каменном богатыре и художественной идеей, которая укладывается в политизированную формулу: Урал-богатырь идет по пути, предназначенному революцией, Лениным и Сталиным. Результат - абсолютная пассивность народа, дождавшегося в лице Ленина “избавителя”» [Слобожанина, 1998, с. 133].

Во многом данная критика справедлива. В сказе мы видим, как место Денежкина Камня, древнего литического тотема Урала, хранящего его богатства в богатырском стакане «выше человеческого росту, много больше сорокаведерной бочки», сделанном «из самолучшего золотистого топаза» [Бажов, 2019, с. 467], занимает «настоящий человек» в кепочке. Этот человек приходит к Денежкину камню без всякого горняцкого или охотничьего снаряжения, объясняя свое 
появление так: «хожу по земле, гляжу, что где полезное народу впусту лежит и как это полезное лучше взять» [Бажов, 2019, с. 471]. Ради этого настоящего человека литический богатырь поднимает богатыреву рукавицу с топазового стакана, полного рудяными да каменными денежками, позволив чудесному путнику посмотреть не только верхнее (в топазовом стакане), но и «низовое богатство» земли, хранящееся в зарытом в землю изумрудном стаканчике. Е.Е. Приказчикова пишет: «Открытие этой великой тайны гор подготавливает двойную финальную метаморфозу сказа. Каменный богатырь, получеловекполугора, окончательно теряет свой антропоморфный облик, приобретая облик литический <..> . Ленин, в образе которого до этого момента еще не было ничего нарочито гиперболизированного и грандиозного, становится новой тайной силой - наследником прошлого величия Уральских гор и хранителем их богатств» [Приказчикова, 2007, с. 230]. Став хранителем богатств, «настоящий человек» в кепочке на глазах у читателей сам превращается в великана, легко поднимающего с земли каменную богатыреву рукавицу и закрывающего ею топазовый стакан со словами: «Пусть полежит вместо покрышки. Все-таки баловства меньше, а приниматься за работу тут давно пора» [Бажов, 2019, с. 473]. После этого он отправляется «своей дорогой прямо на полночь» [Бажов, 2019, c. 473], на запад, еще не озаренный светом новой справедливой жизни. Недостатком финала сказа можно считать тот факт, что литические богатства Денежкина камня в нем, по сути, оказываются скрытыми от людей до лучших времен. Данный недостаток финальной части сказа Бажов исправит впоследствии в «Орлином пере». Однако обращает на себя внимание использование Бажовым для характеристики богатства «самоцветной полосы» топаза и изумруда. Золотистый топаз, один из наиболее любимых уральских камней, является камнем просветления, символом человеческого счастья. Что касается изумруда, то в литической символике он, по мнению Н. Жюльен, «хранитель тайны мироздания и всех живых существ, а также причина всего сущего» [Жюльен, 2000, с. 155].

Последним сказом ленинского цикла является сказ «Орлиное перо», который Л. Слобожанина характеризует так: «сказ... откровенно дидактичен и содержит элементы самоповторения, перекликаясь с довоенным сказом "Ключ земли" (1940)» [Слобожанина, 1998, с. 133].

Момент переклички со сказом «Ключ земли» в «Орлином пере», конечно, присутствует. Однако еще бо́льшая связь просматривается с «Богатыревой рукавицей» в силу того, что в «Орлином пере», по словам Е.Е. Приказчиковой, «Ленин выступает уже не в роли чудесного хранителя, но в роли дарителя <...>. В “Богатыревой рукавице” Ленин наследует литическую мудрость веков, хранителем которой был Денежкин камень, и чудесно преображается в финале под ее влиянием. В “Орлином пере” Ленин ведет себя уже по законам тайной силы» [Приказчикова, 2007, с. 231]. В качестве носителя высшей мудрости Ленин показывает старому горщику из г. Березовска Кондратию Маркелычу три уровня человеческой жизни: воробьиный, утиный да лебединый и орлиный. Каждому 
уровню соответствует свой световой колокол: от самого низкого, воробьиного, предполагающего тяжелый труд на самого себя, до орлиного, который указывает человеку дорогу к получению земных богатств. В последнем случае жизнь человека должна быть посвящена борьбе за счастье других людей.

Литическим символом такой жизни становится в сказе камень орлец, который имеет названия «рубиновый шпат» или родонит. Наименование орлец получил из-за того, что его часто находили в орлиных гнездах. Термин «родонит» в переводе с греческого языка означает роза. Первое месторождение родонита было открыто на Урале еще в середине XVIII века и получило название Малоседельниковское. Оно находилось всего в 25 километрах от Екатеринбурга. Первые документальные свидетельства об уральском родоните относятся к 1792 году. При этом до начала XX века уральское месторождение родонита считалось единственным на планете. С.М. Николаев пишет, что этот камень «пробуждает в человеке скрытые таланты, творческие порывы, развивает любовь к искусству и ко всему прекрасному» [Николаев, 1995, с. 235].

Таким образом, в сказах о Ленине Бажов последовательно выделяет ряд камней (гелиолит, золотистый топаз, изумруд, родонит), которые по внешнему виду и символическим литическим свойствам могут претендовать на статус камней новой советской эпохи. Однако, помимо этих камней, в сказах Бажова второй половины 1940-х гг. появляется образ «терпеливого камешка», напрямую продолжающего тему чудесных камней Урала, начатую образом «Ключа земли». Образ «терпеливого камешка» встречается в сказе «Далевое глядельце».

Сказ «Далевое глядельце» был впервые опубликован в 1946 году в газете «Уральский рабочий». Иногда этот сказ считают творческой неудачей Бажова наряду с другими сказами второй половины 1940-х гг. Например, Л.М. Слобожанинова видела его в ряду «малоинтересных сказов, выдержанных в духе соцреализма» [Слобожанинова, 1998, с. 148]. По мнению Е.Е. Приказчиковой, «“Далевое глядельце”относится к программным для ППБ 1940-х гг. сказам о символических камнях новой советской жизни, открывающих дорогу в будущее, в новую счастливую жизнь» [Приказчикова, 2007, с. 97]. С одной стороны, сказ, безусловно, продолжает литическую традицию «Ключа земли», камня, предназначенного для того, «кто верной дорогой народ поведет» [Бажов, 2019, с. 287]. С другой - «Далевое глядельце» продолжает традицию и сказа «Орлиное перо» в той части, где Ленин показывает горщику Кондратию Маркелычу три уровня человеческой жизни, воробьиный, утиный да лебединый и орлиный, прибавив при этом: «И выше орла, дед, птицы есть, да показать опасаюсь: глаза у тебя не выдержат» [Бажов, 2018, с. 528].

В «Далевом глядельце» это время приходит. «Терпеливый камешек» сказа позволяет увидеть «глядельце», где сходятся все пласты горы. Как объясняет старатель Яша Кочеток, создатель литического мифа о терпеливом камешке: «Глядельце открывается только тому, кто себе выгоды не ждет, а хочет посмотреть красоту горы и народу сказать, что где полезное лежит» [Бажов, 2018, с. 622]. 
При этом, как и в случае с «Ключ-камнем», терпеливый камешек не повторяет буквально черт ни одного из реальных камней, составляющих красоту «самоцветной полосы Урала». Он - предельно символичен и абстрактен. Кочеток объясняет своему молодому ученику и преемнику по горному делу Троше Легонькому: «А какой он этот камешок цветом: голубой ли зеленый, малиновый ли красный, - это неведомо. Одно помнить надо, чтоб его какой своей корыстью не замутить» [Бажов, 2018, с. 622].

Следуя завету наставника, Троша Легонький честно работает всю свою жизнь, «не хитничал, не барышничал», «терпеливых камешков целый мешок накопил, а далевого глядельца так увидеть ему и не пришлось» [Бажов, 2018, c. 624]. Честный упорный труд в горе постепенно превращает Трошу Легонького в Трофима Тяжелую Котомку, однако так и не приближает его к постижению правды основного литического мифа Урала, о котором он услышал в свои молодые годы. Однако в контексте послевоенных взглядов Бажова это поражение отдельного взятого человека, хоть и мастера своего дела, глубоко закономерно. Мудрость новой советской эпохи олицетворяет в сказе внук Трофима, горный инженер. Он говорит старику: «Тридцатый уж год пошел, как твое далевое глядельце открыто всякому, кто смотрит не через свои очки. Зоркому глазу через это глядельце не то что горы, а будущие годы видно» [Бажов, 2019, с. 625]. В результате, как справедливо пишет Е.Е. Приказчикова, «далевое глядельце камня становится “далевым глядельцем” нравственно-этического мира, в котором живет человек» [Приказчикова, 2007, с. 98].

Последним литическим сказом послевоенной эпохи, который был напечатан в «Литературной газете» 24 декабря 1949 года, был сказ «Золотоцветень горы». В отличие от других литических сказов Бажова, этот сказ никогда не входил в состав «Малахитовой шкатулки». Тем не менее «Золотоцветень горы» логично завершает тему чудесных камней советской эпохи. Главным героем сказа является бывший горщик Сидор Васильевич Климин, пребывающий в конце 40-х годов в статусе «советского» старика. В свое время Сидор Климин изучал мастерство горщика у местного знатока работы горщика, «чертозная» Кирило Федотыча, который и поведал юному Сидору сказ о золотоцветне горы. В соответствии с этим сказом каменная «лента украшенья» находится в горной гряде, которую зовут Поясом земли. В длину этот пояс «тысячами верст считают, а сколь он широк и насколько в землю врезался, этого никто толком не знает» [Бажов, 1952, с. 41 ]. Сама «лента украшенья» Пояса Земли представляет собой два уровня. Первый уровень - широкая «лента украшенья», включающая в себя изумруды, аквамарины, аметисты, александриты. Второй уровень, захватывающий самую середку Пояса, состоит из двойного ряда хризолитов, которые в народе называют золотоцветняками. Самый большой хризолит Пояса и является золотоцветнем горы. По мнению чертозная Кирило Федотыча, «перед ним (камнем. - Ю.Я.) все камни, какие из земли добыты, не дороже песку, а то и золы» [Бажов, 1952, с. 41 ]. Сила камня в сказе Бажова заключается в том, что перед человеком, который 
«усмотрит этот камень, Пояс земли раскроется» [Бажов, 1952, с. 41]. Так же, как и в случае с «терпеливым камешком» «Далевого глядельца», камень «золотоцветень горы» открывается лишь тому, кто в горе работает не для себя, не преследует цель личного обогащения. Кирило Федотыч так поучал своего ученика: «Нет, друг, тут другой глаз требуется. Мало того, что он должен быть зоркий, надо еще, чтоб он ни какой корыстью не замутился, не для себя выискивал, а для всего народа» [Бажов, 1952, с. 41]. Единственным отличием финала сказа «Золотоцветень горы» от финала сказа «Далевое глядельце» является обозначение будущего хозяина и хранителя литического богатства Урала. Хозяина, которому удастся открыть далевое глядельце и раскрыть при помощи «золотоцветеня горы» Пояс земли. В «Далевом глядельце» это богатство открывается всякому советскому человеку, который откажется от мелкособственнической морали, начнет смотреть на мир «не через свои очки» [Бажов, 2019, с. 625]. «Золотоцветень горы» продолжает в данном случае традицию сказов о Ленине. Только вместо В.И. Ленина у гор Урала появляется новый хозяин - И.В. Сталин, которому в 1949 году как раз исполнилось 70 лет, поэтому данный сказ можно считать юбилейным и поэтому старый поисковый сказ сбывается таким образом: «Сталинский зоркий, заботливый глаз усмотрел среди наших лесов, увалов да старых разработок золотоцветень горы и указал за него взяться. И Великий Пояс земли раскрылся и показал свои бессчетные богатства на радость трудовому народу, на зависть его врагам. Всем видно, что наша старая гора теперь живет новой жизнью. Бессчетными огнями новых рудников, шахт и заводов горит и переливается золотоцветень нового Сталинского Урала» [Бажов, 1952, с. 42]. Понятно, что после смерти И.В. Сталина и разоблачения культа личности имя «вождя» было убрано из сказа Бажова. В результате, по мнению В.В. Блажеса, происходит «переход от сказовой тональности к очерковой констатации» [Блажес, 2007, с. 159]: «...зоркий, заботливый глаз усмотрел среди наших лесов, увалов да старых разработок золотоцветень горы и указал за него взяться. И Великий Пояс земли раскрылся и показал свои бессчетные богатства на радость трудовому народу, на зависть его врагам. Всем видно, что наша старая гора теперь живет новой жизнью. Бессчетными огнями новых рудников, шахт и заводов горит и переливается золотоцветень нового советского Урала» [Бажов, 1952, с. 42].

Но и с именем «вождя» и без имени вождя финал сказа Бажова не меняет главное: веру в то, что чудесные камни Уральских гор знаменуют собой новый этап в развитии «самоцветного пояса Урала», когда его богатства будут принадлежать всем, кто живет и работает на этой земле. Безусловно, Павел Петрович Бажов был абсолютно искренен, когда в своих военных и послевоенных сказах выражал свою веру в то, что это время наступило.

Bblвoдbl. В статье рассматривается эволюция литического дискурса П.П. Бажова от камней-самоцветов, символизирующих собой дореволюционную жизнь горнозаводского Урала (малахит, медный изумруд, хризолит), до камней, воплощающих собой утопические идеалы нового постреволюционного Урала. 
На примере ряда сказов 1940-х годов: сказы о Ленине («Солнечный камень», «Богатырева рукавица», «Орлиное перо»), «Ключ-камень», «Далевое глядельце», «Золотоцветень горы» - анализируются основные виды «чудесных камней», воплощающих собой образ нового Урала. Помимо вполне реальных, хоть и наполненных новым революционных смыслом, камней (солнечный камень-гелиолит, орлец-родонит, золотой топаз, хризолит-золотоцветень), Бажов создает образы «чудесных камней», каждый из которых является символом счастливого будущего как советского Урала, так и всей советской России в целом. Это, прежде всего, ключ-камень и терпеливый камешек - камни, позволяющие простому человеку увидеть и понять утопический идеал счастливой жизни советского народа, где нет места тяжелому изнуряющему труду, а люди уважают и любят друг друга. С точки зрения 1940-х годов, несмотря на все трудности и суровый был этого времени, данный идеал еще не казался Бажову абсолютно недостижимым.

\section{Библиографический список}

1. Бажов П.П. Письма. 1911-1950 / сост. Г.А. Григорьев, Л.С. Григорьева; науч. ред. М.А. Литовская. М.; Екатеринбург: Кабинетный ученый, 2018. 688 с.

2. Бажов П.П. Малахитовая шкатулка: науч. изд. М.; Екатеринбург: Кабинетный ученый, 2019. $896 \mathrm{c}$.

3. Бажов П.П. Золотоцветень горы // Литературная газета. 1949. 24 дек. 33 с.

4. Блажес В.В. П.П. Бажов и рабочий фольклор: учеб. пособие по спецкурсу для студентов филол. фак. / МВ и ССО РСФСР; Урал. гос. ун-т им. А.М. Горького. Свердловск: УрГУ, 1982. $102 \mathrm{c}$.

5. Блажес В.В., Литовская М.А. Бажовская энциклопедия. Екатеринбург: Сократ; Урал, 2007. $640 \mathrm{c}$.

6. Боголюбов К. Наш Бажов (Воспоминания) // Южный Урал. Литературно-художественный альманах. 1951. № 5. URL: https://www.rulit.me/series/yuzhnyj-ural/yuzhnyj-ural-5-download-323669.html (дата обращения: 30.04.2021).

7. Васильев И. Сказ как форма бажовского повествования // Бажовская энциклопедия. Екатеринбург: Сократ; Урал, 2007. С. 374-377.

8. Виноградов В.В. Проблема сказа в стилистике // Виноградов В.В. Избранные труды: О языке художественной прозы. М.: Наука, 1980. С. 42-55.

9. Гамали О.И., Каневская О.Б. «Каменные образы» в индивидуально-авторской картине мира П.П. Бажова // Вестник Харьковского национального педагогического университета им. Г.С. Сковороды. 2016. № 2 (57). С. 29-34.

10. Граматчикова Н.Б. Этнография детства в сказах П.П. Бажова // П.П. Бажов в меняющемся мире: сб. ст. Второй Всероссийской научной конференции с Международным участием, посвященной 135-летнему юбилею писателя (Екатеринбург, 13-14 февраля 2014 г.). Екатеринбург: Объединенный музей писателей Урала, 2014. С. 25-34.

11. Григорьев Г.А. Павел Петрович Бажов и его письма // Павел Петрович Бажов. Письма. 1911-1950 / сост. Г.А. Григорьев, Л.С. Григорьева; науч. ред. М.А. Литовская. М.; Екатеринбург: Кабинетный ученый, 2018. С. 643-659.

12. Жердев Д.В. Ключ земли // Бажовская энциклопедия. Екатеринбург: Сократ; Урал, 2007. C. 209-210.

13. Жердев Д.В., Литовская М.А. Павел Бажов «Малахитовая шкатулка»: контексты // Павел Петрович Бажов. Письма. 1911-1950 / сост. Г.А. Григорьев, Л.С. Григорьева; науч. ред. М.А. Литовская. М.; Екатеринбург: Кабинетный ученый, 2018. С. 792-818. 
14. Жюльен Н. Словарь символов: Иллюстрированный справочник. Челябинск: Урал Л.Т.Д., 2000. 497 c.

15. Иванова Е.Э. Названия копей самоцветной полосы Урала: номинативные типы и модели // Вопросы ономастики. 2020. Т. 17, № 2. C. 107-134. DOI: 10.15826/vopr_onom.2020.17.2.020

16. Иофе В.В. К пятидесятой годовщине постановления ЦК ВКП(б) О журналах «Звезда» и «Ленинград» от 14 августа 1946 года // Звезда. 1996. № 8. С. 3-25.

17. Круглова Т.А. П.П. Бажов как советский писатель: проблемы идентификации // П.П. Бажов в меняющемся мире: сб. ст. Второй Всероссийской научной конференции с Международным участием, посвященной 135-летнему юбилею писателя (Екатеринбург, 13-14 февраля 2014 г.). Екатеринбург: Объединенный музей писателей Урала, 2014. С. 64-73.

18. Николаев С.М. Камни: мифы, легенды, суеверия. Новосибирск: Наука: Сибирская изд. фирма, 1995. 349 с.

19. Никулина М.П. Камень. Пещера. Гора. Екатеринбург: Банк культурной информации, 2002. $66 \mathrm{c}$.

20. Приказчикова Е.Е. Ленин в сказах П.П. Бажова // Бажовская энциклопедия. Екатеринбург: Сократ; Урал, 2007. С. 228-232.

21. Скорино Л. Павел Петрович Бажов. М.: Советский писатель, 1947. 275 с.

22. Слобожанинова Л.М. Малахитовая шкатулка П.П. Бажова в литературе 30-40-х годов. Екатеринбург: Сократ, 1998. 176 с.

23. Томашевский В.В. Стилистика и стихосложение: курс лекций. Л.: Гос. учеб.-пед. изд-во Министерства просвещения РСФСР, 1959. 534. с.

24. Эйхенбаум Б.М. Иллюзия сказа // Эйхенбаум Б.М. Сквозь литературу. Л.: Академия, 1924. C. $152-156$.

25. Politicizing magic: an anthology of Russian and Soviet fairy tales / ed. by M. Balina, H. Goscilo, and M. Lipovetsky. Northwestern University Press, Illinois, 2005. 418 p.

26. Wan Guangshuang. Analysis of folk tales. Hope publishing house. 2013. 400 p.

\section{Сведения об авторе}

Ян Юйбин - аспирант, Уральский федеральный университет им. Первого Президента России Б.Н. Ельцина (Екатеринбург); е-тail: 914837669@qq.com; https://orcid.org/0000-0002-6499-1267 


\title{
DOI: https://doi.org/10.25146/2587-7844-2021-15-3-87
}

\section{WONDERFUL STONES OF THE SOVIET ERA IN P.P. BAZHOV'S TALES}

\section{Yang Yubing (Yekaterinburg, Russia)}

\begin{abstract}
Problem statement. This article analyzes the lytic component of P. P. Bazhov's tales of the 1940s and proves that these tales continue the tradition laid down by the tales of the 1930s, in which malachite, copper emerald, and chrysolite were the main stones reflecting the specifics of mining life. The lytic discourse of new tales, in which the sun stone, the key-stone, the patient pebble appear, makes it possible to expand the understanding of both the ideological component of the tales and the mythopoetics of the writer's fiction as a whole.

The purpose of the article is to study the lytic component of Bazhov's military and post-war tales, in which the contours of the future happy life of the Soviet people are visible through the image of both real and miraculous stones of the new era.

Methodology. The article uses the methodology of cultural-historical, ideological-figurative, and symbolic-contextual analysis.

Research results and conclusions. The article sequentially examines a number of stones that, in their appearance and in their symbolic properties, can claim the status of stones of the new Soviet era in the Urals. Among these stones we see both real-life stones (heliolite, golden topaz, and rhodonite), which in their appearance and in their symbolic lytic properties can claim the status of stones of the new Soviet era in the "Tales about Lenin", and magical stones (key stone, patient pebble, and golden mountain blossom). The latter make it possible to assess the utopian potential of the happy future of the Soviet Urals, which from the point of view of the 1940s did not seem absolutely unattainable to Bazhov.

Keywords: P.P. Bazhov, tales, lytic discourse, magical stones of the Soviet era (earth key, patient pebble, golden mountain blossom).
\end{abstract}

\section{References}

1. Bazhov P.P. Letters. 1911-1950 / comp. G.A. Grigoriev, L.S. Grigorieva; scientific ed. M.A. Litovskaya. Moscow; Yekaterinburg: Cabinet Academic, 2018. 688 p.

2. Bazhov P. P. Malachite box: scientific publication. Moscow; Esa-Edinburgh: Cabinet Scientist, 2019. 896 p.

3. Bazhov P.P. Zolototsveten gory // Literaturnaya gazeta. 1949. 24 December. 33 p.

4. Blazhes V.V. P.P. Bazhov and working folklore : studies. manual on a special course for students of philology / MV and SSO of the RSFSR; Ural State University named after A.M. Gorky. Sverdlovsk: USU, 1982. 102 p.

5. Blazhes V.V., Litovskaya M.A. Bazhovskaya encyclopedia. Yekaterinburg: Publishing house: Socrates; Publishing house: Ural, 2007. 640 p.

6. Bogolyubov K. Our Bazhov (Memoirs) // Southern Urals. Literary and artistic almanac. 1951. No. 5. URL: https://www.rulit.me/series/yuzhnyj-ural/yuzhnyj-ural-5-download-323669.html (access date: 30.04 .2021 ).

7. Vasiliev I. Skaz as a form of Bazhovsky narration // Bazhovskaya encyclopedia. Yekaterinburg: Publishing house: Socrates; Publishing house: Ural, 2007. P. 374-377.

8. Vinogradov V.V. The problem of a fairy tale in stylistics // Vinogradov V.V. Literary works: On the language of artistic prose. Moscow: Nauka, 1980. P. 42-55. 
9. Gamali O.I., Kanevskaya O.B. "Stone images" in the individual author's picture of the world by P.P. Bazhov // Bulletin of the Kharkiv National Pedagogical University named after G.S. Skovoroda. 2016. № 2 (57). P. 29-34.

10. Gramatikova N.B. Ethnography of childhood in the tales by P. Bazhov // P. Bazhov in a changing world: a collection of articles of the Second all-Russian scientific conference with International participation, dedicated to the 135th anniversary of the writer (Ekaterinburg, 13-14 February 2014). Ekaterinburg: United Museum of writers of the Urals, 2014. S. 25-34.

11. Grigor'ev G.A. Pavel Bazhov and his writing // Pavel Petrovich Bazhov. Letters. 1911-1950 / comp. G.A. Grigoriev, L.S. Grigorieva; scientific ed. M.A. Litovskaya. Moscow; Yekaterinburg: Cabinet Scientist, 2018. P. 643-659.

12. Zherdev D.V. The key of the earth // Bazhovskaya encyclopedia. Yekaterinburg: Publishing house: Socrates; Publishing house: Ural, 2007. P. 209-210.

13. Zherdev D.V., Litovskaya M.A. Pavel Bazhov "Malachite box": contexts // Pavel Petrovich Bazhov. Letters. 1911-1950 / comp. G.A. Grigoriev, L.S. Grigorieva; scientific ed. M.A. Litovskaya. Moscow; Yekaterinburg: K-binet scientist, 2018. P. 792-818.

14. Julien N. Dictionary of symbols: An illustrated reference book. Chelyabinsk: Ural L. T. D., 2000. $497 \mathrm{p}$.

15. Ivanova E.E. Names of mines of the semi-precious strip of the Urals: nominative types and models // Questions of onomastics. 2020. Vol. 17, No. 2. P. 107-134. DOI: 10.15826/vopr_ onom.2020.17.2.020

16. Iofe V.V. On the fiftieth anniversary of the resolution of the Central Committee of the CPSU(b) About the magazines "Zvezda" and "Leningrad" from August 14, 1946 // Zvezda. 1996. No. 8. P. 3-25.

17. Kruglova T.A. P.P. Bazhov as the Soviet writer: problem identification // P. Bazhov in a changing world: a collection of articles of the Second All-Russian scientific conference with International participation, dedicated to the 135th anniversary of the writer (Ekaterinburg, 13-14 February 2014). Ekaterinburg: United Museum of writers of the Urals, 2014. S. 64-73.

18. Nikolaev S.M. Jewels: the myths, legends, superstitions. Novosibirsk: Nauka: Siberian publishing house of the firm, $1995.349 \mathrm{p}$.

19. Nikulina M.P. Kamen. Cave. Mountain. Yekaterinburg: Publishing house: Bank of Cultural Information, 2002. $66 \mathrm{p}$.

20. Prikazchikova E.E. Lenin in the tales of P.P. Bazhov // Bazhovskaya encik-lopedia. Yekaterinburg: Publishing house: Socrates; Publishing house: Ural, 2007. P. 228-232.

21. Skarino L. Pavel Petrovich Bazhov. Moskow: Soviet writer, 1947. 275 p.

22. Slobozhaninova L.M. P.P. Bazhov's malachite casket in the literature of the 30-40s. Yekaterinburg: Socrates Publishing House, 1998. 176 p.

23. Tomashevsky V.V. Stylistics and versification: a course of lectures. L.: State textbook.-ped. publishing house of the Ministry of Education of the RSFSR, 1959. 534. p.

24. Eichenbaum B.M. The illusion of a fairy tale // Eichenbaum B.M. Through literature. L.: Akademiya, 1924. P. 152-156.

25. Politicizing magic: an anthology of Russian and Soviet fairy tales / ed. by Marina Balina, Helena Goscilo, and Mark Lipovetsky. Northwestern University Press, Illinois, 2005. 418 p.

26. Wan Guangshuang. Analysis of folk tales. Hope publishing house. 2013. 400 p.

\section{About the author}

Yang Yubing - PhD Candidate, Ural Federal University named after the first President of Russia B.N. Yeltsin (Yekaterinburg); e-mail: 914837669@qq.com; https://orcid.org/0000-0002-6499-1267 